\title{
MODEL PENINGKATAN KOMPETENSI SUMBERDAYA MANUSIA PADA SEKTOR PARIWISATA DI KOTA BANDUNG SEBAGAI UPAYA MENINGKATKAN DAYA SAING SEKTOR PARIWISATA
}

\author{
Rofi Rofaida (rrofaida@yahoo.com) \\ Universitas Pendidikan Indonesia
}

\begin{abstract}
ABSTRAK
Perkembangan sektor pariwisata tidak terlepas dari kemajuan industri hotel dan restoran. Kontribusi sektor terhadap PDRB, penyerapan tenaga kerja, dan adanya peningkatan jumlah entitas usaha menunjukkan bahwa aktifitas ekonomi sektor ini tetap tinggi dan menjadi andalan Kota Bandung. Namun demikian permasalahan yang terjadi terkait dengan SDM adalah rendahnya tingkat penyerapan tenaga kerja disebabkan adanya ketidaksesuaian antara kompetensi yang dimiliki dengan kebutuhan industri.
\end{abstract}

Tujuan dari kajian ini adalah :

1) Menyusun strategi peningkatan kompetensi SDM pada sektor hotel dan restoran yang berbasis pada analisis kesenjangan antara profil kompetensi SDM yang dibutuhkan dengan profil kompetensi SDM yang ada saat ini.

2) Melakukan pemetaan dan analisis peran sistem 'triple helix' (industri, pemerintah dan akademisi) dalam menyusun model peningkatan kompetensi SDM

Hasil penelitian terhadap karyawan front office, tatagraha, pramusaji, dan cook/koki menunjukkan bahwa kompetensi yang dimiliki belum memenuhi standar yang ditetapkan SKKNI untuk bidang hotel dan restoran. Strategi Peningkatan Kompetensi SDM yang diajukan terdiri dari : (1). Peningkatan kapasitas lembaga diklat (2). Peningkatan kompetensi SDM melalui pelatihan, dan (3) Peningkatan kompetensi SDM melalui program sertifikasi dan standarisasi

Peningkatan kompetensi SDM ditentukan oleh tiga faktor, yaitu : industri, kebijakan pemerintah, dan institusi pendidikan. Pemetaan dan analisis peran sistem 'triple helix' (industri, pemerintah dan akademisi) akan menghasilkan Model Peningkatan Kompetensi SDM Sektor Hotel dan Restoran.

Kata kunci : kompetensi, Standar Kompetensi Kerja Nasional Indonesia (SKKNI), pelatihan, dan model peningkatan kompetensi SDM

\section{PENDAHULUAN}

\section{Latar Belakang}

Sesuai dengan visi "Memantapkan Kota Bandung sebagai Kota Jasa yang BERMARTABAT", seperti yang tercantum dalam Rencana Pembangunan Jangka Menengah Daerah (RPJMD) tahun 2009-2013, Pemerintah Kota Bandung menjadikan sektor jasa sebagai sektor unggulan pembangunan yang diharapkan dapat menjadi motor penggerak perekonomian Kota Bandung. Pariwisata, yang produk utamanya adalah jasa pelayanan, merupakan bagian tak terpisahkan bahkan menjadi andalan pembangunan sektor jasa Kota 
Bandung. Peran strategis sektor pariwisata terhadap perekonomian kota Bandung dapat dilihat dari kontribusi terhadap pendapatan asli daerah (PAD). Kontribusi sektor pariwisata terhadap PAD Kota Bandung meningkat dari 66\% atau Rp176 miliar pada tahun 2011 menjadi 72\% pada tahun 2012 (http://diskominfo.jabarprov.go.id dan bisnis-jabar.com).

Perkembangan sektor pariwisata tidak dapat dilepaskan dari kemajuan industri hotel dan restoran. Salah satu sasaran pembangunan pariwisata kota Bandung adalah meningkatkan jumlah kunjungan dan memperpanjang lama tinggal wisatawan. Pada kurun waktu 20052008 terdapat peningkatan jumlah kunjungan wisatawan nusantara dan wisatawan mancanegara yang sebagian besar memanfaatkan fasilitas akomodasi dan makanan di kota Bandung (Disbudpar Kota Bandung 2008 dan BPS Kota Bandung 2011). Statistical Report on Visitor Arrivals to Indonesia, Disbudpar Jawa Barat 2008, menunjukkan bahwa sebagian besar pengeluaran wisatawan baik wisatawan mancanegara maupun wisatawan nusantara adalah untuk akomodasi dan dari beberapa pilihan akomodasi, 74,98 \% memilih hotel.

Gambar 1.

Tipe Akomodasi yang dipilih Wisatawan

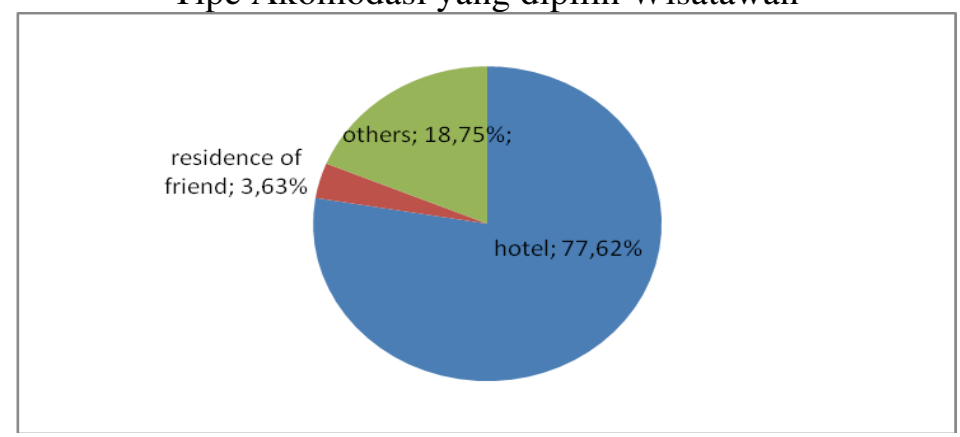

Sumber: Statistical Report on Visitor Arrivals to Indonesia, Disbudpar Jawa Barat (2008)

Jumlah kunjungan yang meningkat merupakan peluang investasi yang menguntungkan bagi sektor hotel dan restoran. Aktifitas ekonomi di sektor ini diharapkan dapat memberikan kontribusi dalam pengurangan tingkat pengangguran sekaligus peningkatan pendapatan masyarakat Kota Bandung. Potensi penyerapan tenaga kerja sektor ini cukup tinggi dilihat dari beberapa indikator, yaitu :

1) Kontribusi sektor terhadap PDRB Kota Bandung saat ini dan proyeksi nya untuk tahun 2013-2015

2) Kontribusi sektor dalam penyerapan tenaga kerja saat ini dan proyeksinya untuk tahun 2013-2015

3) Pertumbuhan populasi usaha

Kontribusi sektor terhadap PDRB Kota Bandung saat ini dan proyeksi nya untuk tahun 20132015 menunjukkan bahwa untuk kurun waktu 2013-2015 peranan sektor perdagangan, hotel, dan restoran tetap tinggi. Tabel 1.1 di bawah ini menunjukkan bahwa pada tahun 2013 sektor ini memberikan kontribusi sebesar 42,21\% dan meningkat menjadi 42,83\% (tahun 2014) dan 43,37 (tahun 2015). Ini memberikan gambaran bahwa pada tiga tahun yang akan datang potensi ekonomi sektor ini akan tetap tinggi dan menjadi andalan.

Pada aspek penyerapan tenaga kerja sektor ini juga memberikan kontribusi terbesar jika dibandingkan dengan sektor ekonomi yang lain. Tabel 1.1 menunjukkan bahwa tahun 2011 
jumlah tenaga kerja yang bekerja pada sektor perdagangan, restoran, dan hotel sebesar 369.161 orang dan diperkirakan akan terus meningkat untuk tahun 2013-2015.

Tabel 1.1

Kontribusi Sektor Perdagangan, Hotel dan Restoran terhadap PDRB dan Penyerapan Tenaga Kerja di Kota Bandung Tahun 2013-2015

\begin{tabular}{|l|r|r|r|r|}
\hline & 2011 & $2013^{*}$ & $2014^{*}$ & $2015^{*}$ \\
\hline $\begin{array}{l}\text { Kontribusi terhadap PDRB Kota } \\
\text { Bandung }\end{array}$ & $40,64 \%$ & $42,21 \%$ & $42,83 \%$ & $43,37 \%$ \\
\hline $\begin{array}{l}\text { Kontribusi terhadap penyerapan } \\
\text { tenaga kerja }\end{array}$ & 369.161 & 396.304 & 412.879 & NA \\
\hline
\end{tabular}

Ket: * nilai proyeksi

Sumber : BPS Kota Bandung (2012), diolah

Khusus untuk hotel, populasi jumlah hotel terus mengalami peningkatan. Jumlah kunjungan wisatawan merupakan peluang investasi yang menguntungkan sehingga jumlah hotel di kota Bandung terus meningkat. Tabel 1.2 di bawah ini menunjukkan perkembangan jumlah hotel melati, hotel bintang 1, 2, 3, 4, dan 5 di kota Bandung.

Tabel 1.2

Perkembangan Jumlah Hotel di Kota Bandung

\begin{tabular}{|l|rrrrrrrr|}
\hline Tahun & $\begin{array}{c}\text { Hotel non } \\
\text { bintang }\end{array}$ & Bintang $\mathbf{1}$ & $\begin{array}{c}\text { Bintang } \\
\mathbf{2}\end{array}$ & \multicolumn{1}{c}{$\begin{array}{c}\text { Bintang } \\
\mathbf{3}\end{array}$} & $\begin{array}{c}\text { Bintang } \\
\mathbf{4}\end{array}$ & $\begin{array}{c}\text { Bintang } \\
\mathbf{5}\end{array}$ & $\begin{array}{c}\text { Jumlah } \\
\text { hotel } \\
\text { bintang }\end{array}$ \\
\hline $\mathbf{2 0 0 7}$ & NA & 7 & 16 & 23 & 11 & 4 & 61 \\
\hline $\mathbf{2 0 0 8}$ & NA & 7 & 16 & 27 & 15 & 4 & 69 \\
\hline $\mathbf{2 0 0 9}$ & NA & 10 & 15 & 26 & 15 & 6 & 72 \\
\hline $\mathbf{2 0 1 0}$ & NA & 7 & 16 & 28 & 19 & 7 & 77 \\
\hline $\mathbf{2 0 1 2}$ & 189 & 9 & 18 & 29 & 20 & 8 & 84 \\
\hline
\end{tabular}

Sumber : Disbudpar Kota Bandung (2008) dan BPS Kota Bandung (2012)

Kecuali untuk tahun 2009 terdapat peningkatan jumlah hotel berbintang selama periode tahun 2007-2012 dari 61 buah pada tahun 2007 menjadi 84 buah pada tahun 2012 atau meningkat sebesar 23\% dalam waktu lima tahun. Diproyeksikan pada lima tahun ke depan jumlah hotel bintang dan non bintang akan semakin meningkat.

Namun demikian salah satu permasalahan terkait dengan sumberdaya manusia di sektor hotel dan restoran adalah rendahnya tingkat penyerapan tenaga kerja. Data yang diperoleh dari Dinas Tenaga Kerja Kota Bandung yang dikutip oleh BPS Kota Bandung (2011) menunjukkan dari 2010 hingga 2011 terjadi penurunan daya serap tenaga kerja. Pada tahun 2010 sekitar 62,71\% maka tahun 2011 hanya 32,69 \%. Hal ini disebabkan adanya ketidaksesuaian antara kompetensi yang dimiliki dengan kebutuhan dunia usaha.

Studi yang dilakukan pada sektor pariwisata menunjukkan bahwa kompetensi SDM di hotel dan restoran belum memenuhi standar pelayanan yang diterima secara nasional (SKKNI) dan memerlukan peningkatan kompetensi melalui pelatihan yang berorientasi pada katan kebutuhan sektor hotel dan restoran saat ini dan yang akan datang. Peningkatan kompetensi menjadi suatu hal yang mutlak untuk dilakukan jika dikaitkan dengan adanya kemudahan bagi tenaga kerja asing untuk masuk ke Indonesia. Ini merupakan 
ancaman bagi tenaga kerja Indonesia jika tidak diimbangi dengan kemampuan yang memenuhi standar pelayanan dan sertifikasi secara nasional atau internasional

Pendidikan merupakan hal yang amat penting dalam meningkatkan kualitas sumber daya manusia (SDM). Namun, sampai saat ini belum sepenuhnya terjadi link and match (keterkaitan dan kecocokan) antara dunia pendidikan dengan dunia usaha. Dengan kata lain belum terjadi sinkronisasi antara lembaga penyelenggara pendidikan dengan perkembangan lapangan pekerjaan. Dampaknya adalah banyak lulusannya yang kemudian tidak terserap oleh pasar kerja dan meningkatkan tingkat pengangguran.

Didasarkan pada uraian di atas, dianggap penting untuk melakukan penelitian berkaitan dengan : Model Peningkatan Kompetensi Sumberdaya Manusia Pada Sektor Pariwisata Di Kota Bandung Sebagai Upaya Meningkatkan Daya Saing Sektor Pariwisata

\section{Rumusan Masalah dan Tujuan Penelitian}

Beberapa masalah yang dapat diidentifikasi berkaitan dengan peningakatan kompetensi SDM pada sektor hotel dan restoran diuraikan sebagai berikut:

1) Masih terbatasnya kajian untuk melakukan identifikasi dan analisis berkaitan dengan profil kompetensi SDM sektor hotel dan restoran yang dibutuhkan pasar seperti : tingkat pendidikan dan keahlian/skill yang dibutuhkan

2) Masih terbatasnya kajian berkaitan dengan profil kompetensi SDM sektor hotel dan restoran di Kota Bandung yang ada saat ini berkaitan dengan: tingkat pendidikan dan keahlian/skill yang dibutuhkan

3) Perlu dilakukan pemetaan/mapping dan analisis kesenjangan antara poin (2), dan (3) di atas sehingga dapat disusun strategi peningkatan kompetensi SDM sektor hotel dan restoran di Kota bandung

4) Perlu dilakukan pemetaan dan analisis peran sistem 'triple helix' (industri, pemerintah dan akademisi) dalam peningkatan kompetensi SDM untuk menyusun model peningkatan kompetensi SDM sektor hotel dan restoran di Kota bandung

Tujuan dari kajian ini adalah :

1) Menyusun strategi peningkatan kompetensi SDM pada sektor hotel dan restoran yang berbasis pada analisis kesenjangan terhadap dua aspek penting yaitu profil kompetensi SDM yang dibutuhkan pasar/aspek permintaan (demand) dengan profil kompetensi SDM yang ada saat ini/aspek ketersediaan (supply). Analisis dilakukan secara sistematis dan komprehensif

2) Hasil analisis ini juga dapat dijadikan informasi bagi industri dalam melakukan training needs assessment (analisis kebutuhan pelatihan). Bagi institusi pendidikan hasil penelitian dalam menyempurnakan kurikulum untuk meningkatkan link and match antara pendidikan dengan kebutuhan industri

3) Melakukan pemetaan dan analisis peran sistem 'triple helix' (industri, pemerintah dan akademisi) dalam menyusun model peningkatan kompetensi SDM

4) Menyediakan rujukan dalam kerangka penyusunan rencana-rencana yang lebih operasional dan teknis, bagi Disnaker Kota Bandung agar program dan kegiatan yang akan diimplementasikan dapat saling bersinergi, baik antar kebijakan, antar program 
sektoral dan wilayah dalam kerangka mengoptimalkan kompetensi SDM di sektor hotel dan restoran kota Bandung

\section{LANDASAN TEORI}

\section{Kompetensi (Competency)}

Sumberdaya manusia dalam pariwisata merupakan salah satu faktor sangat penting karena bagi perusahaan jasa (service-based organization). SDM berperan sebagai faktor kunci dalam menentukan kinerja perusahaan. Hal ini tidak terlepas dari salah satu karakteristik jasa dimana proses penghantaran jasa akan terjadi bersamaan dengan proses konsumsi jasa oleh pelanggan. Karakteristik ini menuntut kinerja SDM dalam membangkitkan minat dan memberikan pelayanan prima/service excellent kepada pelanggan. Pengalaman tamu hotel atau restoran merupakan aktifitas yang memiliki intensitas dan intimasi yang sangat tinggi dan tidak mudah direplikasi oleh entitas usaha yang lain. Pengalaman interaktif tersebut umumnya terjadi dengan karyawan sehingga kualitas pelayanan yang diberikan oleh karyawan akan menjadi salah satu keunggulan bersaing bagi hotel atau restoran. Pendidikan dan pelatihan memberikan kontribusi yang sangat besar dalam menciptakan SDM yang andal dan profesional baik secara kuantitas maupun kualitas dalam mendorong daya saing sektor hotel dan restoran secara signifikan.

Salah satu permasalahan rendahnya daya serap tenaga kerja adalah karena adanya kesenjangan antara kompetensi yang dibutuhkan industri dengan kompetensi yang dimiliki tenaga kerja. Beberapa ahli mendefinisikan istilah kompetensi sebagai berikut:

1. Competence encompasses an individual's technical and interpersonal knowledge and skills (Robbin, Stephen P 2010:357). Kompetensi merupakan pengetahuan dan skill individu secara teknik dan interpersonal

2. A competency is an underlying characteristics on individual that is causally related to criterion referenced effective and/or superior performance in a job or situation (Spencer and Spencer 1993:9). Kompetensi berkaitan dengan ciri dasar idividu yang dikaitkan dengan standar kinerja yan efektif dan atau superior

3. Competence refers to an individual's knowledge, skill, abilities or personality characteristics that directly influences his or her performances (Becker, Huselid, dan Ulrich dalam Yuniarsih dan Suwatno 2008:22). Kompetensi merupakan pengetahuan, keahlian, kemampuan, dan kepribadian yang secara langsung mempengaruhi kinerjanya.

Dari ketiga definisi di atas, dapat disimpulkan bahwa kompetensi adalah karakteristik berupa pengetahuan, keahlian, dan kepribadian yang mempengaruhi kinerja individu. Salah satu model kompetensi yang diterima secara baik oleh sektor akademis dan praktisi adalah model kompetensi yang dikemukakan oleh Spencer dan Spencer (1993:11). Model tersebut terdapat pada Gambar 2.1.

Spencer and Spencer (1993:9) menyatakan terdapat 5 karakteristik kompetensi yaitu:

1. motif (motive), secara konsisten merupakan apa yang mendorong (memotivasi individu melakukan sesuatu)

2. ciri bawaan (trait), ciri fisik dan reaksi yang bersifat kosisten terhadap apa yang terjadi dai lingkungan

3. konsep diri (self concept), nilai diri, cara individu memandang dirinya sendiri 
4. pengetahuan (knowledge), informasi yang dimiliki seseorang tentang sesuatu hal

5. keterampilan (skill), kemampuan melaksanakan tuas-tugas fisik dan mental.

Pengetahuan dan keterampilan cenderung lebih tampak (visible) dan relatif mudah untuk dikembangkan melalui program pelatihan. Motif dan ciri bawaan berada pada lingkaran di tengah merupakan faktor yang tersembunyi sehingga sulit sekali untuk dinilai dan dikembangkan. Terakhir adalah konsep diri, Nerada pada lingkaran ditengah-tengah, artinya sikap, nilai dan nilai diri dapat diubah melalui pelatihan dan psikoterapi atau pengalaman pengembangan yang positif, walaupun memerlukan jangka waktu yang lama.

Gambar 2.1

Model Kompetensi

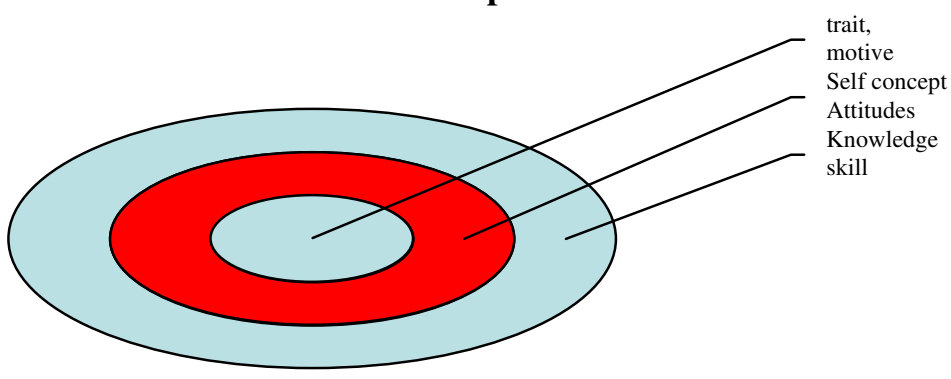

Sumber : Spencer and Spencer, 1993, p.11,

Competence at Work: Model for Superior Performance, John Wiley \&Sons, Inc, New York

\section{Standar Kompetensi Kerja Nasional Indonesia (SKKNI)}

Model Kompetensi Spencer and Spencer menjadi rujukan dalam menyusun standar kompetensi nasional termasuk didalamnya untuk sektor pariwisata. Kompetensi menurut Undang Undang No. 13 tahun 2003 tentang ketenagakerjaan adalah : kemampuan kerja setiap individu yang mencakup aspek pengetahuan, keterampilan, dan sikap kerja yang sesuai dengan standar yang ditetapkan. Standar kompetensi kerja untuk Indonesia tertuang dalam SKKNI (Standar Kompetensi Kerja Nasional Indonesia) yang dikeluarkan oleh Keputusan Menteri Tenaga Kerja dan Transmigrasi. Standar Kompetensi Kerja Nasional Indonesia (SKKNI) adalah uraian kemampuan yang mencakup pengetahuan, keterampilan dan sikap kerja minimal yang harus dimiliki untuk menduduki jabatan tertentu. Standar kompetensi kerja merupakan rumusan yang benar-benar dikerjakan di tempat kerja pada industri.

Hingga saat ini SKKNI telah dibakukan dengan Keputusan Menteri Tenaga Kerja dan Transmigrasi adalah sebanyak 14 standar. Pengembangan sertifikasi kompetensi kerja yang dilakukan oleh BNSP terkait dan terpadu dengan pengembangan Standar Kompetensi Kerja Nasional Indonesia (SKKNI) serta pengembangan pelatihan berbasis kompetensi di lembagalembaga pelatihan kerja sebagai kesatuan Sistem Latihan Kerja Nasional (SISLATKERNAS). Sesuai dengan Pasal 18 ayat (1), (2) dan (3) Undang-Undang No. 13 tahun 2003, sertifikasi kompetensi kerja adalah bentuk pengakuan secara formal terhadap kompetensi kerja yang telah dikuasai.

Standar kompetensi untuk ketenagakerjaan hotel dan restoran diatur berdasarkan Penetapan Standar Kompetensi Kerja Nasional Indonesia (SKKNI) Sektor Pariwisata Sub Sektor Hotel dan Restoran melalui KepMen 239/MEN/X/2004. Pengukuran kompetensi SDM pada kajian ini mengacu pada SKKNI Sub Sektor Hotel Dan Restoran 
Arah Kebijakan ketenagakerjaan Kota bandung juga memfokuskan peningaktan kualitas SDM melalui standarisasi pelayanan, akreditasi lembaga, dan sertifikasi profesi. Berdasarkan Perda Kota Bandung No. 07 Tahun 2012 BAB X tentang Pelatihan Sumberdaya Manusia, standarisasi, Sertifikasi, dan Tenaga Kerja, menyebutkan beberapa hal, yaitu :

1) Tenaga kerja di bidang kepariwisataan memiliki standar kompetensi. Standar kompetensi dilakukan atau diperoleh melalui sertifikasi kompetensi

2) Sertifikasi kompetensi dilakukan oleh lembaga sertifikasi profesi yang memiliki lisesnsi sesuai dengan ketentuan peraturan perundangan

3) Produk, pelayanan, danpengelolaan usaha memiliki standar usaha

4) Standar usaha dilakukan melalui sertifikasi usaha

5) Pemerintah Daerah menyelenggarakan pelatihan SDM pariwisata untuk memenuhi standar kompetensi sesuai dengan ketentuan peraturan perundang-undangan

\section{METODE PENELITIAN}

\section{Metode Penelitian}

Obyek studi adalah Model Peningkatan Kompetensi Sumberdaya Manusia Pada Sektor Pariwisata Di Kota Bandung Sebagai Upaya Meningkatkan Daya Saing Sektor Pariwisata. Studi dilakukan pada hotel dan restoran di Kota Bandung. Penelitian ini dilakukan secara kualitatif. Metode yang digunakan adalah metode survei . Survei dilakukan pada karyawan front office dan tatagraha hotel sedangkan untuk restoran adalah pramusaji dan cook/koki. Penetapan empat jenis pekerjaan ini karena empat jenis pekerjaan berinteraksi langsung dan memberikan kontribusi terbesar bagi penghantaran /delivery jasa kepada konsumen. Pengamatan menggunakan cakupan waktu "one shoot" / cross sectional. Analisis dilakukan secara deskriptif.

Pengukuran variabel penelitian dapat dijelaskan pada matriks operasionalisasi variabel di bawah ini :

Tabel 3.1

Tabel Operasionalisasi Variabel

\begin{tabular}{|c|c|c|c|c|}
\hline & Variabel & Sub Variabel & & Indikator yang diukur \\
\hline 1 & $\begin{array}{l}\text { Kompetensi SDM sektor } \\
\text { hotel dan restoran yang } \\
\text { dimiliki saat ini }\end{array}$ & $\begin{array}{l}\text { Kompetensi front office } \\
\text { sesuai dengan SKKNI Sektor } \\
\text { Pariwisata Sub Sektor Hotel } \\
\text { dan Restoran }\end{array}$ & $\begin{array}{l}\text { a) } \\
\text { b) } \\
\text { c) } \\
\text { d) } \\
\text { e) }\end{array}$ & $\begin{array}{l}\text { Indikator : Menerima dan memproses reservasi : } \\
\text { - Menerima permintaan reservasi } \\
\text { - Mencatat rincian reservasi } \\
\text { Indikator : Menyediakan layanan akomodasi } \\
\text { - Menyiapkan kedatangan tamu } \\
\text { - Menyambut dan mendaftarkan } \\
\text { - Mengorganisir keberangkatan tamu } \\
\text { Indikator : Memproses transaksi keuangan } \\
\text { Indikator : Berkomunikasi melalui telepon } \\
\text { Indikator : Menyediakan jasa porter }\end{array}$ \\
\hline & & $\begin{array}{l}\text { Kompetensi tatagraha sesuai } \\
\text { dengan SKKNI Sektor } \\
\text { Pariwisata Sub Sektor Hotel } \\
\text { dan Restoran }\end{array}$ & & $\begin{array}{l}\text { Indikator : Menyediakan layanan housekeeping untuk } \\
\text { tamu : } \\
\text { a) Menangani permintaan housekeeping } \\
\text { b) Memberi saran tamu mengenai perlengkapan } \\
\text { housekeeping } \\
\text { Indikator : Menyiapkan kamar untuk tamu } \\
\text { a) Akses ke kamar untuk pelayanan } \\
\text { b) Membereskan tempat tidur } \\
\text { c) Membereskan dan membersihkan kamar } \\
\text { Indikator: Menangani pakaian tamu }\end{array}$ \\
\hline
\end{tabular}




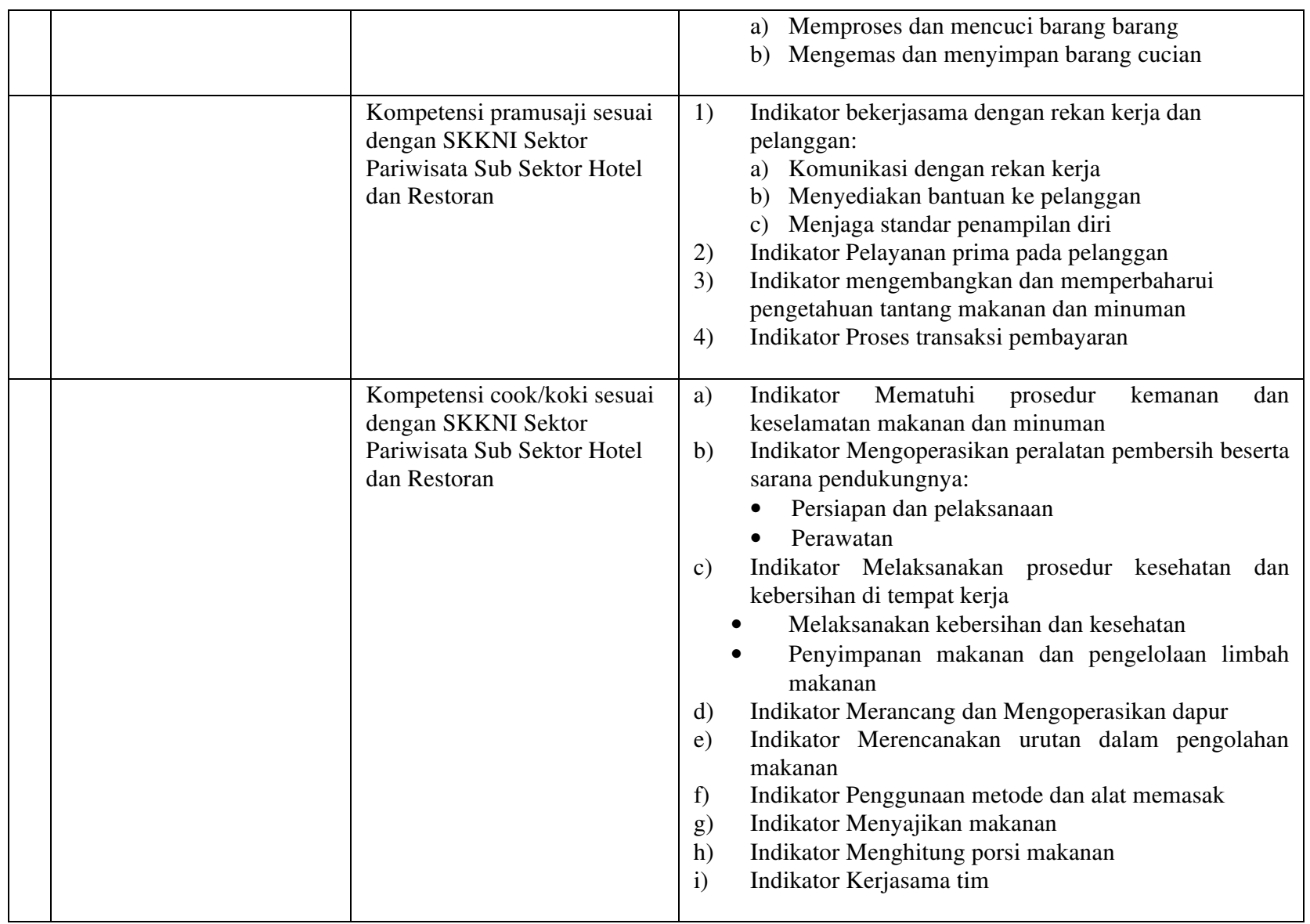

\section{Metode Pengumpulan Data}

Untuk menjawab tujuan kegiatan seperti disebutkan di atas maka dilakukan pengumpulan data primer dan data sekunder. Pengumpulan data primer dilakukan dengan melakukan observasi, wawancara, survey, expert justification, dan FGD. Pengumpulan data sekunder dilakukan melalui desk study. Matriks variabel penelitian dan metode pengumpulan data yang dilakukan dapat dijelaskan pada Tabel 3.2

Tabel 3.2

Matrik Metode Pengumpulan Data

\begin{tabular}{|c|l|c|}
\hline $\mathbf{1}$ & $\begin{array}{l}|c| \\
\text { Kompetensi SDM sektor hotel dan restoran yang } \\
\text { dibutuhkan pasar }\end{array}$ & $\begin{array}{l}\checkmark \\
\text { Observasi lapangan,Survey dan in depth } \\
\text { interview, dan desk study }\end{array}$ \\
\hline $\mathbf{2}$ & $\begin{array}{l}\text { Kompetensi SDM sektor hotel dan restoran di Kota } \\
\text { Bandung yang ada saat ini }\end{array}$ & $\begin{array}{l}\text { Observasi lapangan,Survey dan in depth } \\
\text { interview, dan desk study }\end{array}$ \\
\hline $\mathbf{4}$ & $\begin{array}{l}\text { Kebijakan berkaitan dengan peningkatan SDM Sektor } \\
\text { Hotel dan Restoran }\end{array}$ & $\checkmark$ Desk study,FGD, dan expert justification \\
\hline
\end{tabular}

\section{Teknik Penarikan Sampel}

Populasi pada penelitian ini adalah sektor hotel dan restoran di Kota Bandung. Penarikan sampel dilakukan dengan metode purposive sampling. Purposive sampling adalah teknik sampling yang digunakan jika peneliti mempunyai pertimbangan tertentu didalam pengambilan sampelnya, atau disebut juga sebagai sampel untuk tujuan tertentu. Penelitian 
kualitatif biasanya menggunakan non probability sampling (termasuk di dalamnya purposive sampling) (Arikunto 2010:33). Sampel hotel terdiri dari hotel berbintang 4, 3, dan 2 sedangkan restoran terdiri dari restoran nusantara, barat, dan cepat saji.

Sumber data / responden adalah karyawan front office dan tatagraha hotel sedangkan untuk restoran adalah pramusaji dan cook/koki. Penetapan empat jenis pekerjaan ini karena empat jenis pekerjaan berinteraksi langsung dan memberikan kontribusi terbesar bagi penghantaran /delivery jasa kepada konsumen.

Penilaian kompetensi dilakukan dengan penyebaran kuesioner kepada konsumen yang pernah menggunakan layanan hotel dan kepada karyawan. Penyebaran kuesioner dilakukan kepada konsumen dan karyawan hotel dilakukan karena ada beberapa item kompetensi yang tidak terkait langsung dengan konsumen sehingga tidak bisa dinilai oleh konsumen. Metode penilaian untuk kuesioner kompetensi yang disebarkan kepada karyawan digunakan metode self appraisal method .

\section{Metode Analisis Data}

Item pertanyaan dalam kuesioner disusun dengan skala likert 1-5. Sesuai dengan tujuan yang ingin dicapai, maka data yang diperoleh dianalisis dengan tahapan:

1. Menyusun data mengecek kelengkapan identitas responden dan pengisian kuesioner

2. Tabulasi Data, dilakukan untuk mengelompokkan data berdasarkan indikator

3. Identifikasi, pemetaan/mapping dan analisis deskriptif berkaitan dengan profil kompetensi SDM sektor hotel dan restoran yang dibutuhkan pasar

4. Identifikasi, pemetaan/mapping dan analisis deskriptif berkaitan dengan profil kompetensi SDM sektor hotel dan restoran yang ada saat ini

5. Melakukan analisis kesenjangan (gap analysis) antara poin (3), dan (4) sehingga dapat disusun kebijakan peningkatan kompetensi termasuk didalamnya kebijakan pendidikan dan pelatihan yang seharusnya dilakukan industri maupun Disnaker Kota Bandung

6. Hasil analisis ini juga dapat dijadikan informasi bagi industri dalam melakukan training needs assessment (analisis kebutuhan pelatihan). Bagi institusi pendidikan hasil penelitian dalam menyempurnakan kurikulum untuk meningkatkan link and match antara pendidikan dengan kebutuhan industri

7. Pemetaan dan analisis peran sistem 'triple helix' (industri, pemerintah dan akademisi) dalam peningkatan kompetensi SDM

Data diolah dan disajikan dalam bentuk distribusi frekuensi, tabulasi silang, disajikan berdasarkan kesamaan karakteristik atau dibandingkan untuk memahami fenomena, atau diolah agar mudah digunakan untuk pengolahan analisis deskriptif 


\section{Kerangka Kerja Penelitian}

Gambar 3.1

Kerangka Kerja Penelitian

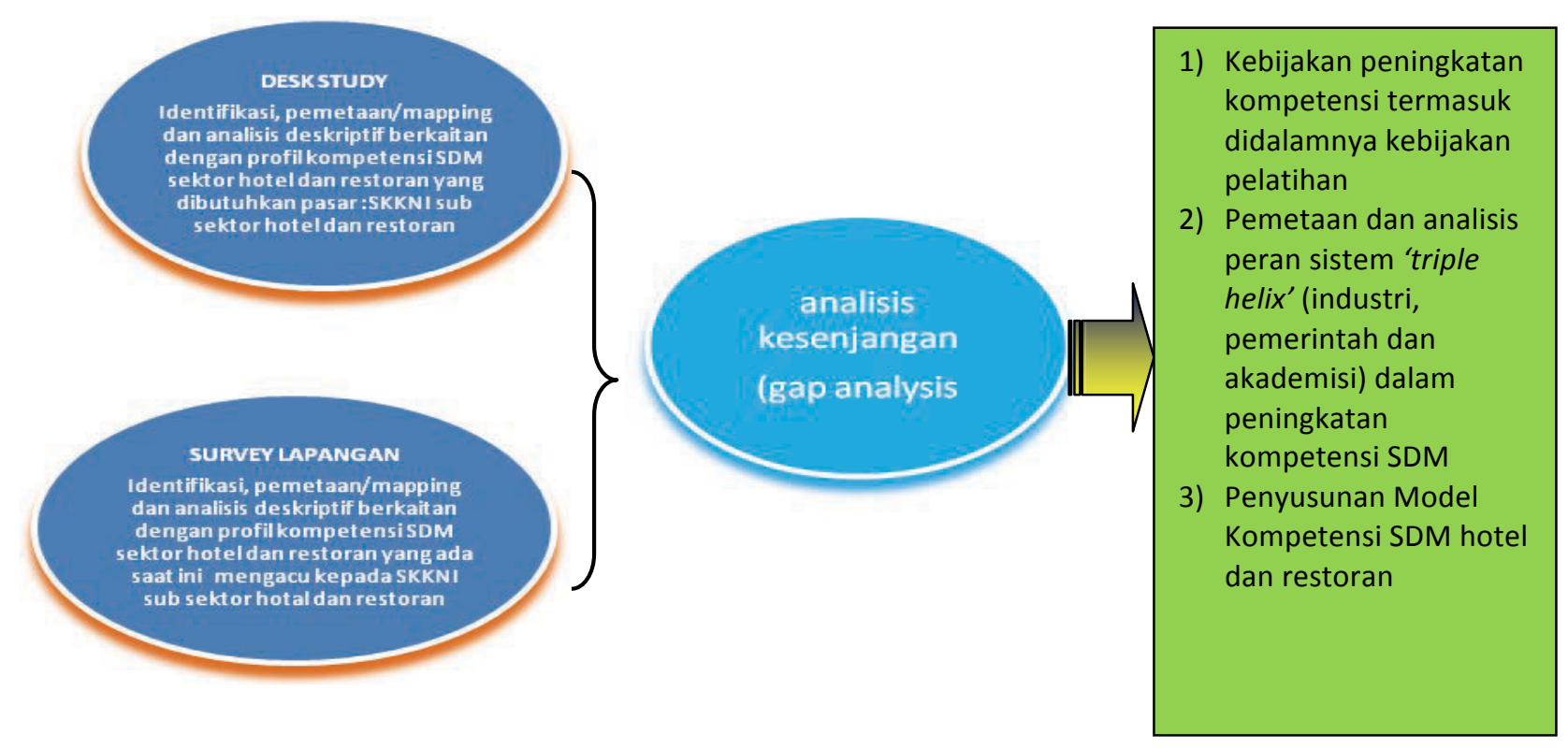

\section{HASIL DAN PEMBAHASAN}

Identifikasi, pemetaan/mapping dan analisis deskriptif berkaitan dengan profil kompetensi SDM sektor hotel dan restoran yang dibutuhkan pasar

Indikator kompetensi front office mengacu pada SKKNI berdasarkan Penetapan Standar Kompetensi Kerja Nasional Indonesia Sektor Pariwisata Sub Sektor Hotel Dan Restoran Keputusan Menteri : Kep 239/MEN/X/2004. Indikator yang masuk dalam ruang lingkup kajian adalah sebagai berikut:

\section{Front office hotel :}

a) Indikator : Menerima dan memproses reservasi :

- Menerima permintaan reservasi

- Mencatat rincian reservasi

b) Indikator : Menyediakan layanan akomodasi

- Menyiapkan kedatangan tamu

- Menyambut dan mendaftarkan

- Mengorganisir keberangkatan tamu

c) Indikator : Memproses transaksi keuangan

d) Indikator : Berkomunikasi melalui telepon

e) Indikator : Menyediakan jasa porter

\section{Tata graha hotel}

a) Indikator : Menyediakan layanan housekeeping untuk tamu :

- Menangani permintaan housekeeping

- Memberi saran tamu mengenai perlengkapan housekeeping 
b) Indikator : Menyiapkan kamar untuk tamu

- Akses ke kamar untuk pelayanan

- Membereskan tempat tidur

- Membereskan dan membersihkan kamar

c) Indikator : Menangani pakaian tamu

- Memproses dan mencuci barang barang

- Mengemas dan menyimpan barang cucian

\section{Pramusaji Restoran}

a) Indikator bekerjasama dengan rekan kerja dan pelanggan:

- Komunikasi dengan rekan kerja

- Menyediakan bantuan ke pelanggan

- Menjaga standar penampilan diri

b) Indikator Pelayanan prima pada pelanggan

c) Indikator mengembangkan dan memperbaharui pengetahuan tantang makanan dan minuman

d) Indikator Proses transaksi pembayaran

\section{Cook / Koki}

a) Indikator Mematuhi prosedur kemanan dan keselamatan makanan dan minuman

b) Indikator Mengoperasikan peralatan pembersih beserta sarana pendukungnya:

- Persiapan dan pelaksanaan

- Perawatan

c) Indikator Melaksanakan prosedur kesehatan dan keberseihan di tempat kerja

- Melaksanakan kebersihan dan kesehtan

- Penyimpanan makanan dan pengelolaan limbah makanan

d) Indikator Merancang dan Mengoperasikan dapur

e) Indikator Merencanakan urutan dalam pengolahan makanan

f) Indikator Penggunaan metode dan alat memasak

g) Indikator Menyajikan makanan

h) Indikator Menghitung porsi makanan

i) Indikator Kerjasama tim

\section{Identifikasi, Pemetaan/mapping dan Analisis Deskriptif Berkaitan dengan Profil Kompetensi SDM Sektor hotel dan Restoran saat ini}

\section{Analisis Deskriptif Berkaitan dengan Profil Kompetensi Front Office}

Hasil penelitian menunjukkan bahwa secara keseluruhan kompetensi kompetensi front office di hotel belum memperoleh hasil yang sempurna yaitu skor 5. Artinya kompetensi real karyawan masih di bawah kompetensi yang diharapkan. Masih ada gap/kesenjangan antara kompetensi ekspektasi dengan kompetensi real nya. Namun analisis lebih lanjut menunjukkan bahwa keseluruhan indikator kompetensi berada pada skor di atas 3,00 (cukup baik) kecuali untuk indikator menerima dan memproses permintaan reservasi rata-rata skor masih di bawah 3,00 yaitu 2,96. Hasil selengkapnya dapat dilihat pada Tabel 4.1 
Tabel 4.1

Profil Kompetensi Front Office

\begin{tabular}{|c|c|c|c|}
\hline $\begin{array}{l}\text { Indikator kompetensi } \\
\text { dengan skor tertinggi }\end{array}$ & $\begin{array}{l}\text { Sub indikator } \\
\text { kompetensi dengan } \\
\text { skor tertinggi }\end{array}$ & $\begin{array}{c}\text { Indikator } \\
\text { kompetensi dengan } \\
\text { skor terendah }\end{array}$ & $\begin{array}{l}\text { Sub indikator kompetensi } \\
\text { dengan skor terendah }\end{array}$ \\
\hline $\begin{array}{l}\text { 1) Menyediakan } \\
\text { layanan akomodasi, } \\
\text { dengan skor } \\
\text { kompetensi } 3,30 \text { dan } \\
\text { skor gap } 1,70\end{array}$ & $\begin{array}{l}\text { 1) Permintaan tamu } \\
\text { untuk bantuan } \\
\text { keberangkatan } \\
\text { dilakukan dengan } \\
\text { sopan dan ditujukan } \\
\text { ke departemen yang } \\
\text { berkaitan, dengan skor } \\
\text { kompetensi } 3,45 \text { dan } \\
\text { skor gap 1,55 } \\
\text { 2) Express check-outs } \\
\text { dan rekening diproses } \\
\text { sesuai dengan } \\
\text { prosedur perusahaan } \\
\text { dengan skor } \\
\text { kompetensi } 3,60 \text { dan } \\
\text { skor gap } 1,40\end{array}$ & $\begin{array}{l}\text { Menerima dan } \\
\text { memproses reservasi }\end{array}$ & 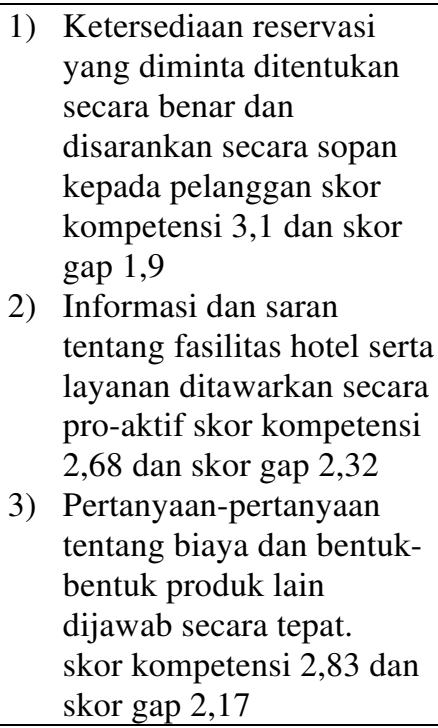 \\
\hline $\begin{array}{l}\text { 2) Menyediakan jasa } \\
\text { porter, dengan skor } \\
\text { kompetensi } 3,58 \text { dan } \\
\text { skor gap } 1,43\end{array}$ & $\begin{array}{l}\text { Tamu-tamu disambut } \\
\text { segera dan dibantu } \\
\text { dengan barang- } \\
\text { barang bawaan sesuai } \\
\text { dengan prosedur } \\
\text { perusahaan dan } \\
\text { persyaratan } \\
\text { keselamatan dengan } \\
\text { skor kompetensi } 3,58 \\
\text { dan skor gap } 1,42 \\
\end{array}$ & $\begin{array}{l}\text { Menyediakan layanan } \\
\text { akomodasi }\end{array}$ & $\begin{array}{l}\text { informasi dan saran tentang } \\
\text { fasilitas dan layanan lain } \\
\text { seperti fasilitas safety deposit } \\
\text { ditawarkan secara pro-aktif } \\
\text { skor kompetensi 3,00 dan skor } \\
\text { gap 2,00 }\end{array}$ \\
\hline 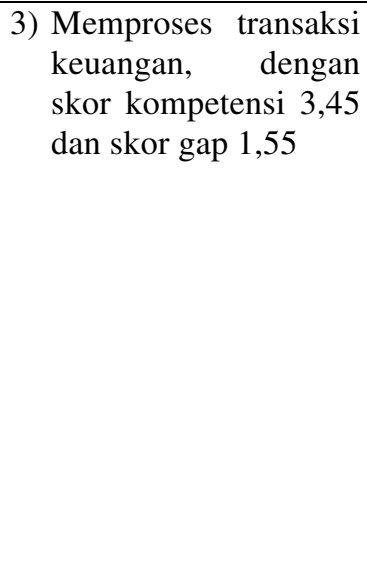 & $\begin{array}{ll}\checkmark & \text { Tagihan tamu } \\
\text { diterangkan secara } \\
\text { jelas dan sopan } \\
\text { kepada tamu, dan } \\
\text { diproses secara akurat } \\
\text { dengan skor } \\
\text { kompetensi 3,35 dan } \\
\text { skor gap 1,65 } \\
\checkmark \text { Transaksi } \\
\text { pembayaran dicatat } \\
\text { dengan benar dan } \\
\text { segera. dengan skor } \\
\text { kompetensi 3,45 dan } \\
\text { skor gap 1,55 }\end{array}$ & $\begin{array}{l}\text { Berkomunikasi } \\
\text { melalui telpon }\end{array}$ & $\begin{array}{l}\text { telepon dijawab secara cepat, } \\
\text { jelas dan sopan } \\
\text { skor kompetensi } 3,23 \text { dan skor } \\
\text { gap } 1,77\end{array}$ \\
\hline
\end{tabular}

Dari Tabel 4.1 dapat diketahui bahwa indikator yang masih harus ditingkatkan adalah: menerima dan memproses reservasi, menyediakan layanan akomodasi dan berkomunikasi melalui telpon. Karyawan front office kurang mampu menginformasikan dan menawarkan keseluruhan produk/layanan hotel/fasilitas hotel. Hanya menerima dan memproses reservasi tanpa adanya upaya pro aktif untuk mempromosikan dan menawarkan fasilitas-fasilitas lain di luar pemesanan konsumen. Lima sub indikator kompetensi dengan skor rendah (lihat Tabel 4.1) merupakan area pengembangan atau menjadi program pelatihan yang menjadi prioritas Disnaker Kota Bandung. 


\section{Analisis Deskriptif Berkaitan dengan Profil Kompetensi Tata Graha}

Secara keseluruhan kompetensi belum memperoleh hasil yang sempurna yaitu skor 5. Artinya kompetensi real karyawan masih di bawah kompetensi yang diharapkan. Namun analisis lebih lanjut menunjukkan bahwa keseluruhan indikator kompetensi berada pada skor di atas 3,00 (cukup baik). Artinya potensi peningkatan kompetensi masih cukup luas. Pengolahan data memberikan hasil skor kompetensi untuk setiap indikator, seperti dapat dilihat pada Tabel 4.2 di bawah ini :

Tabel 4.2

Profil Kompetensi Tata Graha

\begin{tabular}{|c|c|c|c|}
\hline $\begin{array}{l}\text { Indikator Kompetensi } \\
\text { dengan skor tertinggi }\end{array}$ & $\begin{array}{l}\text { Sub indikator kompetensi } \\
\text { dengan skor tertinggi }\end{array}$ & $\begin{array}{c}\text { Indikator } \\
\text { kompetensi } \\
\text { dengan skor } \\
\text { terendah }\end{array}$ & $\begin{array}{l}\text { Sub indikator kompetensi } \\
\text { dengan skor terendah }\end{array}$ \\
\hline $\begin{array}{l}\text { 1) Menyiapkan kamar } \\
\text { tamu dengan skor } \\
\text { tertinggi yaitu } 3,66 \\
\text { dan nilai gap sebesar } \\
1,34 \text {. }\end{array}$ & $\begin{array}{l}\text { 1) Tempat tidur } \\
\text { dibersihkan, bantal dan } \\
\text { linen diperiksa, noda } \\
\text { dihilangkan sesuai } \\
\text { dengan prosedur } \\
\text { perusahaan dengan skor } \\
\text { 3,73 dan nilai gap } \\
\text { sebesar } 1,27 \text {. } \\
\text { 2) Seprai tempat tidur } \\
\text { diganti sesuai dengan } \\
\text { standar dan prosedur } \\
\text { perusahaan dengan skor } \\
\text { 3,73 dan nilai gap } \\
\text { sebesar } 1,27\end{array}$ & $\begin{array}{l}\text { Menyediakan } \\
\text { layanan } \\
\text { housekeeping }\end{array}$ & $\begin{array}{l}\text { 1) Permintaan ditangani } \\
\text { dengan cara yang ramah } \\
\text { dan sopan sesuai dengan } \\
\text { standar layanan pelanggan } \\
\text { perusahaan dan prosedur } \\
\text { keamanan, skor } \\
\text { kompetensi } 3,33 \text { dan skor } \\
\text { gap } 1,77 \\
\text { 2) Tamu diberi saran dengan } \\
\text { sopan tentang penggunaan } \\
\text { peralatan yang benar, skor } \\
\text { kompetensi } 3,10 \text { dan skor } \\
\text { gap } 1,90 \\
\text { 3) Pertanyaan-pertanyaan } \\
\text { tentang biaya dan bentuk- } \\
\text { bentuk produk lain } \\
\text { dijawab secara tepat, skor } \\
\text { kompetensi } 2,83 \text { dan skor } \\
\text { gap 2,17 }\end{array}$ \\
\hline \multirow[t]{3}{*}{ 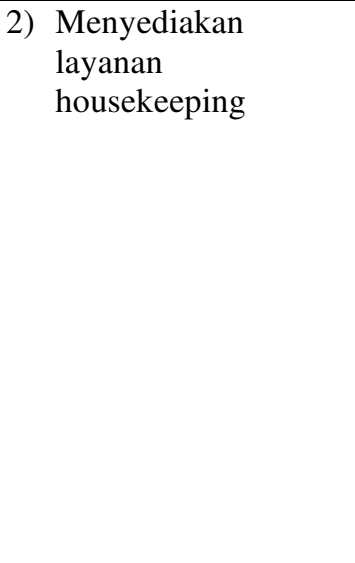 } & \multirow[t]{3}{*}{$\begin{array}{l}\text { Rincian permintaan } \\
\text { dikonfirmasi dan dicatat } \\
\text { dengan skor 3,70 dan nilai } \\
\text { gap sebesar } 1,30\end{array}$} & $\begin{array}{l}\text { Menangani linen } \\
\text { dan pakaian tamu }\end{array}$ & $\begin{array}{l}\text { Proses pencucian, menyeterika } \\
\text { dilaksanakan dengan benar } \\
\text { dan hasil akhir berkualitas } \\
\text { baik, skor kompetensi } 3,35 \\
\text { dan skor gap } 1,65\end{array}$ \\
\hline & & & $\begin{array}{l}\text { Cucian tamu dikemas dan } \\
\text { disajikan dengan baik, skor } \\
\text { kompetensi 3,45 dan skor gap } \\
1,55\end{array}$ \\
\hline & & $\begin{array}{l}\text { Menyediakan } \\
\text { pelayanan valet }\end{array}$ & $\begin{array}{l}\text { Informasi dan saran tentang } \\
\text { layanan khusus dan manfaat } \\
\text { diberikan secara pro-aktif } \\
\text { pada tamu, skor kompetensi } \\
\text { 3,23 dan skor gap } 1,77\end{array}$ \\
\hline
\end{tabular}

Sumber : pengolahan data, 2013

Dari Tabel 4.2 dapat diketahui bahwa terdapat tiga indikator yang memiliki skor tertinggi yaitu: Menyiapkan kamar tamu dan menyediakan layanan housekeeping (pada sub indikator rincian permintaan dikonfirmasi dan dicatat). 
Indikator yang masih harus ditingkatkan adalah: menyediakan layanan housekeeping, menangani linen dan pakaian, serta menyediakan layanan valet. Tujuh sub indikator kompetensi dengan skor rendah (lihat Tabel 4.2) adalah area pengembangan atau menjadi program pelatihan prioritas.

\section{Analisis Deskriptif Berkaitan dengan Profil Kompetensi Pramusaji}

Tabel 4.3 menunjukkan bahwa secara keseluruhan kompetensi pramusaji belum memperoleh hasil yang sempurna yaitu skor 5. Artinya kompetensi real karyawan masih di bawah kompetensi yang diharapkan. Masih ada gap/kesenjangan antara kompetensi ekspektasi dengan kompetensi real nya. Tetapi jika dibandingkan dengan kompetensi SDM pada sektor perhotelan (frontoffice dan tata graha) maka gambaran kompetensi pramusaji menunjukkan gambaran yang lebih baik. Sebagian besar item kompetensi yaitu 52,90\% memiliki skor di atas 4,00 ( kompetensi baik). Sisanya yaitu 47,10\% memiliki nilai di atas 3,40. Seluruh indikator kompetensi memiliki skor di atas 3,40. Ini merupakan indikasi bahwa SDM pramusaji memiliki potensi untuk mencapai kompetensi yang maksimal (skor 5).

Tabel 4.3

Profil Kompetensi Pramusaji

\begin{tabular}{|c|c|c|c|}
\hline $\begin{array}{l}\text { Indikator kompetensi } \\
\text { dengan skor tertinggi }\end{array}$ & $\begin{array}{c}\text { Sub indikator kompetensi } \\
\text { dengan skor tertinggi }\end{array}$ & $\begin{array}{c}\text { Indikator } \\
\text { kompetensi dengan } \\
\text { skor terendah }\end{array}$ & $\begin{array}{l}\text { Sub indikator kompetensi } \\
\text { dengan skor terendah }\end{array}$ \\
\hline $\begin{array}{l}\text { Pelayanan prima pada } \\
\text { pelanggan }\end{array}$ & $\begin{array}{l}\text { 1. Menyambut kedatangan } \\
\text { pelanggan dengan ramah } \\
\text { dan menempatkan } \\
\text { pelanggan di meja yang } \\
\text { telah ditetapkan, dengan } \\
\text { skor kompetensi } 4,43 \text { dan } \\
\text { skor gap } 0,57 \\
\text { 2. Membersihkan meja pada } \\
\text { waktu yang tepat selama } \\
\text { makan dan penyelesaian } \\
\text { makan, dengan skor } \\
\text { kompetensi } 4,40 \text { dan skor } \\
\text { gap } 0,60\end{array}$ & $\begin{array}{l}\text { bekerjasama } \\
\text { dengan rekan kerja }\end{array}$ & $\begin{array}{l}\text { 1. } \begin{array}{l}\text { Harapan dan keperluan } \\
\text { pelanggan termasuk }\end{array} \\
\text { kepentingan khusus, } \\
\text { diperhatikan dan } \\
\text { disediakan dengan } \\
\text { produk layanan yang } \\
\text { tepat, skor kompetensi } \\
\text { 3,64 dan skor gap 1,36 } \\
\text { 2. } \begin{array}{l}\text { Keluhan tamu segera } \\
\text { dipahami dan diambil }\end{array} \\
\text { solusi pemecahannya, } \\
\text { skor kompetensi } 3,45 \\
\text { dan skor gap 2,55 }\end{array}$ \\
\hline \multirow[t]{2}{*}{$\begin{array}{l}\text { Mengembangkan dan } \\
\text { memperbaharui } \\
\text { pengetahuan tantang } \\
\text { makanan dan minuman }\end{array}$} & $\begin{array}{l}\text { Bantuan kepada pelanggan } \\
\text { dalam memilih makanan dan } \\
\text { minuman, disediakan sesuai } \\
\text { Kebutuhan, dengan skor } \\
\text { kompetensi } 4,40 \text { dan skor gap } \\
0,60\end{array}$ & $\begin{array}{l}\text { Pelayanan prima } \\
\text { pada pelanggan }\end{array}$ & $\begin{array}{l}\text { Menyajikan makanan sesuai } \\
\text { yang dipesan oleh } \\
\text { pelanggan, skor kompetensi } \\
3,80 \text { dan skor gap } 1,20\end{array}$ \\
\hline & $\begin{array}{l}\text { Saran pelanggan dalam } \\
\text { mengkombinasikan } \\
\text { makanan dan minuman } \\
\text { ditanggapi, dipilih dan diikuti } \\
\text { atau ditindaklanjuti, dengan } \\
\text { skor } 4,51 \text { dan gap } 0,49\end{array}$ & $\begin{array}{l}\text { Proses transaksi } \\
\text { pembayaran }\end{array}$ & $\begin{array}{l}\text { Memberikan tagihan kepada } \\
\text { pelanggan dengan sopan, } \\
\text { skor kompetensi } 3,82 \text {, gap } \\
1,18\end{array}$ \\
\hline
\end{tabular}

Sumber : pengolahan data, 2013

Hal yang menjadi area pengembangan/pelatihan adalah pada aspek kerjasama tim. Restoran memerlukan kerjasama tim sehingga kompetensi untuk bekerjasama dengan rekan kerja secara efektif dan efisien sangat diperlukan. 


\section{Analisis Deskriptif Berkaitan dengan Profil Kompetensi Cook/Koki}

Tabel 4.4 menunjukkan bahwa secara keseluruhan kompetensi cook memberikan hasil yang lebih baik jika dibandingkan dengan kompetensi pramusaji. Rata rata kompetensi tiap indikator lebih dari 4,00 (kompetensi baik). Beberapa item kompetensi bahkan memperoleh skor sempurna yaitu 5 .

Tabel 4.4

Profil Kompetensi Cook/Koki

\begin{tabular}{|c|c|c|c|}
\hline $\begin{array}{c}\text { Indikator } \\
\text { kompetensi dengan } \\
\text { skor tertinggi }\end{array}$ & $\begin{array}{l}\text { Sub indikator kompetensi dengan } \\
\text { skor tertinggi }\end{array}$ & $\begin{array}{l}\text { Indikator kompetensi } \\
\text { dengan skor terendah }\end{array}$ & $\begin{array}{l}\text { Sub indikator kompetensi } \\
\text { dengan skor terendah }\end{array}$ \\
\hline $\begin{array}{l}\text { Merancang dan } \\
\text { mengoperasikan } \\
\text { dapur }\end{array}$ & $\begin{array}{l}\text { 1. Item menu dimasak, } \\
\text { didinginkan dan dikemas } \\
\text { sesuai dengan prosedur usaha, } \\
\text { peraturan dan } \\
\text { persyaratan kesehatan dengan } \\
\text { skor kompetensi } 5,0 \text { dan skor } \\
\text { gap } 0,0 \\
\text { 2. Produk yang sudah dimasak } \\
\text { disajikan secara tepat dan } \\
\text { menarik untuk memenuhi } \\
\text { keinginan } \\
\text { pelanggan dengan skor } \\
\text { kompetensi } 5,0 \text { dan skor gap } \\
0,0\end{array}$ & $\begin{array}{l}\text { bekerjasama dengan } \\
\text { rekan kerja }\end{array}$ & $\begin{array}{l}\text { 1) Harapan dan keperluan } \\
\text { pelanggan termasuk } \\
\text { kepentingan khusus, } \\
\text { diperhatikan dan } \\
\text { disediakan dengan } \\
\text { produk layanan yang } \\
\text { tepat, skor kompetensi } \\
\text { 3,64 dan skor gap } 1,36 \\
\text { 2) Keluhan tamu segera } \\
\text { dipahami dan diambil } \\
\text { solusi pemecahannya, } \\
\text { skor kompetensi } 3,45 \\
\text { dan skor gap } 2,55\end{array}$ \\
\hline $\begin{array}{l}\text { Perencanaan } \\
\text { Urutan makanan }\end{array}$ & 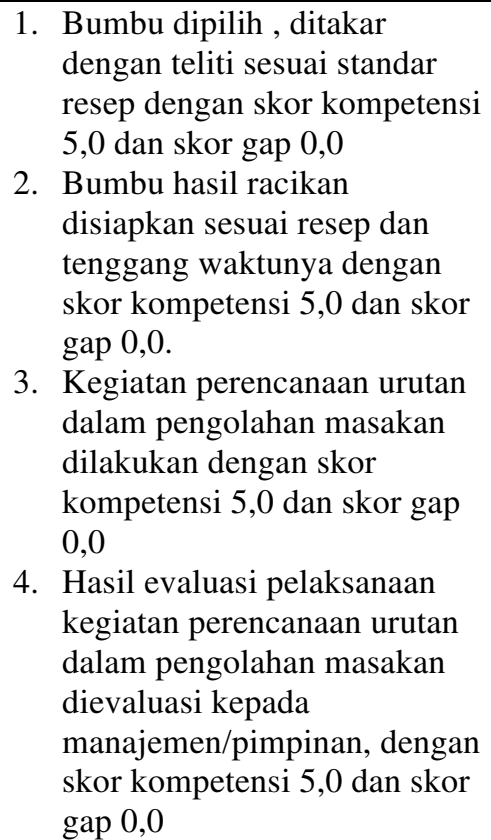 & $\begin{array}{l}\text { Pelayanan prima pada } \\
\text { pelanggan }\end{array}$ & $\begin{array}{l}\text { Menyajikan makanan } \\
\text { sesuai yang dipesan oleh } \\
\text { pelanggan, skor } \\
\text { kompetensi } 3,80 \text { dan skor } \\
\text { gap } 1,20\end{array}$ \\
\hline
\end{tabular}

Sumber : pengolahan data, 2013

\section{Strategi Peningkatan Kompetensi SDM Sektor Hotel dan Restoran}

Terdapat beberapa hal penting berkaitan dengan kompetensi SDM sektor hotel dan restoran yaitu:

1. Persaingan dengan tenaga kerja asing

2. Tuntutan standarisasi layanan/kompetensi 
3. Tuntutan sertifikasi profesi

4. Optimalisasi Lembaga pendidikan dan pelatihan

Berkaitan dengan hal tersebut di atas strategi yang dapat diajukan berkaitan dengan peningkatan kompetensi ketenagakerjaan dilakukan pada : (1). Strategi Peningkatan kapasitas kelembagaan, (2). Strategi Peningkatan kompetensi SDM melalui pelatihan, dan (3) Strategi Peningkatan kompetensi SDM melalui program sertifikasi dan standarisasi

\section{Strategi Peningkatan Kapasitas Lembaga Pendidikan dan Pelatihan}

Beberapa program dilakukan terkait strategi peningkatan kapasitas kelembagaan. Lembaga pendidikan sebagai pelaku pengembangan SDM dari sisi supply, berperan penting untuk dapat menghasilkan SDM yang berkualitas, dan memiliki kompetensi yang sesuai dengan kebutuhan di pasar kerja.

1. Program Peningkatan Kualitas Sistem Pengajaran

a. Peningkatan kapasitas lembaga agar mampu menyusun program dan kurikulum yang bertaraf nasional dan internasional namun sesuai dengan kebutuhan SDM.

b. Peningkatan kemampuan lembaga pendidikan baik formal maupun non-formal dalam penyelenggaraan program diklat sertifikasi keahlian profesi yang dibutuhkan industri

2. Program Peningkatan Kualitas Tenaga Pengajar

Peningkatan kemampuan tenaga pengajar di lembaga pendidikan dan pelatihan melalui program beasiswa di dalam maupun di luar negeri, dan pelatihan berbasis pada standard ASEAN maupun internasional.

3. Peningkatan Sarana dan Prasarana

a. Penetapan standar minimal ketersediaan sarana prasarana pendidikan bagi lembaga pendidikan untuk dapat memenuhi kebutuhan proses pembelajaran yang kondusif.

b. Pemanfaatan teknologi seperti ICT, seperti internet dan multimedia dalam meningkatkan penerapan metode teknik dan strategi pembelajaran.

\section{Strategi Peningkatan Kompetensi SDM melalui Pelatihan}

Definisi pelatihan menurut UU no 13 tahun 2003 adalah : keseluruhan kegiatan untuk memberi, memperoleh, meningkatkan, serta mengembangkan kompetensi kerja, produktivitas, disiplin, sikap, dan etos kerja pada tingkat keterampilan dan keahlian tertentu sesuai dengan jenjang dan kualifikasi jabatan atau pekerjaan.

Fokus utama pelatihan adalah meningkatkan kemampuan karyawan untuk melaksanakan pekerjaan saat ini sedangkan pendidikan meliputi proses pembelajaran di luar pekerjaan saat ini dan lebih fokus pada jangka panjang (long-term focus) Starting point dalam pelatihan adalah adanya penilaian kebutuhan (needs assessment) yang bertujuan untuk mengumpulkan informasi dan melakukan analisis untuk menentukan perlu tidaknya pelatihan dilakukan. Perlu dilakukan identifikasi jenis kompetensi yang dibutuhkan saat ini dan yang akan datang untuk menentukan jenis pelatihan yang akan diberikan. Jika terjadi kesenjangan antara kompetensi yang dibutuhkan dengan yang tersedia maka perlu dilakukan pelatihan. 
Dari hasil analisis kesenjangan (gap analysis) terhadap kompetensi SDM sektor hotel dan restoran dapat disusun pada matriks penilaian kebutuhan (needs assessment) dan jenis pelatihan didasarkan pada pebilaian kebutuhan pelatihan.

Tabel 4.5

Matrik Area Kebutuhan Pelatihan pada Sektor Hotel dan Restoran Kota Bandung

\begin{tabular}{|c|c|c|}
\hline Jenis pekerjaan & Kompetensi yang perlu ditingkatkan & Jenis pelatihan \\
\hline \multirow[t]{5}{*}{ Front office hotel } & $\begin{array}{l}\text { Ketersediaan reservasi yang diminta ditentukan secara benar dan } \\
\text { disarankan secara sopan kepada pelanggan. }\end{array}$ & \multirow{4}{*}{$\begin{array}{l}\text { Pelatihan berkaitan dengan } \\
\text { product knowledge } \\
\text { Pelatihan untuk } \\
\text { meningkatkan kemampuan } \\
\text { promosi produk }\end{array}$} \\
\hline & $\begin{array}{l}\text { Informasi dan saran tentang fasilitas hotel serta layanan ditawarkan } \\
\text { secara pro-aktif. }\end{array}$ & \\
\hline & $\begin{array}{l}\text { Pertanyaan-pertanyaan tentang biaya dan bentuk-bentuk produk lain } \\
\text { dijawab secara tepat }\end{array}$ & \\
\hline & $\begin{array}{l}\text { Informasi dan saran tentang fasilitas dan layanan lain seperti fasilitas } \\
\text { safety deposit ditawarkan secara pro-aktif. }\end{array}$ & \\
\hline & Telepon dijawab secara cepat, jelas dan sopan & Pelatihan berkomunikasi \\
\hline \multirow[t]{5}{*}{$\begin{array}{l}\text { Housekeeping } \\
\text { /tata graha }\end{array}$} & $\begin{array}{l}\text { menangani permintaan tamu dengan cara yang ramah dan sopan } \\
\text { sesuai dengan standar layanan pelanggan perusahaan dan prosedur } \\
\text { keamanan }\end{array}$ & \multirow{2}{*}{$\begin{array}{ll}\text { - } & \text { Pelatihan pelayanan prima } \\
\text { - } & \text { Pelatihan problem solving } \\
\text { - } & \text { Pelatihan kemampuan } \\
& \text { berkomunikasi }\end{array}$} \\
\hline & $\begin{array}{l}\text { kemampuan untuk memberikan saran kepada tamu tentang } \\
\text { penggunaan peralatan hotel dengan sopan }\end{array}$ & \\
\hline & $\begin{array}{l}\text { melakukan proses pencucian, menyeterika dengan benar dan hasil } \\
\text { akhir berkualitas baik }\end{array}$ & \multirow[t]{2}{*}{$\begin{array}{l}\text { Pelatihan pencucian dan } \\
\text { pengemasan barang }\end{array}$} \\
\hline & pengemasan dan penyajian cucian tamu dengan baik & \\
\hline & $\begin{array}{l}\text { memberikan informasi dan saran tentang layanan khusus dan manfaat } \\
\text { diberikan hotel secara pro-aktif }\end{array}$ & $\begin{array}{l}\text { - } \\
\text { Pelatihan berkaitan dengan } \\
\text { - } \quad \text { Pelatihan untuk peningkatkan } \\
\text { kemampuan melakukan } \\
\text { promosi produk } \\
\end{array}$ \\
\hline \multirow[t]{10}{*}{ Pramusaji } & $\begin{array}{l}\text { memperhatikan dan menyediakan produk layanan yang tepat sesuai } \\
\text { dengan harapan dan keperluan pelanggan }\end{array}$ & \multirow{2}{*}{$\begin{array}{ll}\text { - } & \text { Pelatihan product knowledge } \\
\text { - } & \text { Pelatihan pelayanan prima } \\
\text { - } & \text { Pelatihan problem solving } \\
\text { - } & \text { Pelatihan berkomunikasi }\end{array}$} \\
\hline & memahami keluhan tamu dan mengambil solusi pemecahannya. & \\
\hline & menyajikan makanan sesuai yang dipesan oleh pelanggan & \multirow[t]{2}{*}{ Pelatihan pelayanan prima } \\
\hline & memberikan tagihan kepada pelanggan dengan sopan & \\
\hline & $\begin{array}{l}\text { Mensortir dan membuang limbah sesuai dengan } \\
\text { peraturan kesehatan dan praktek perusahaan. }\end{array}$ & $\begin{array}{l}\text { Pelatihan kesehatan dan kemanan } \\
\text { lingkungan kerja }\end{array}$ \\
\hline & $\begin{array}{l}\text { Mengidentifikasi dan menggunakan perlengkapan masak sesuai } \\
\text { kebutuhan dan metoda memasak masakan tertentu }\end{array}$ & \multirow{3}{*}{$\begin{array}{ll}\text { - } & \text { Pelatihan penggunaan metode } \\
\text { memasak yang tepat sesuai } \\
\text { urutan pengolahan makanan } \\
\text { - } \quad \text { Pelatihan penggunaan alat } \\
\text { sesuai dengan standar } \\
\text { keamanan dan kesehatan } \\
\end{array}$} \\
\hline & $\begin{array}{l}\text { Menggunakan alat memasak yang bersih dan aman sesuai dengan } \\
\text { menu dan standar perusahaan. }\end{array}$ & \\
\hline & $\begin{array}{l}\text { Melakukan evaluasi secara berkala dari pihak manajemen terhadap } \\
\text { penggunaan metode dan alat memasak }\end{array}$ & \\
\hline & $\begin{array}{l}\text { Kerja sama di dapur untuk layanan makanan ditampilkan untuk } \\
\text { memaksimalkan mutu makanan dan mengurangi keterlambatan. }\end{array}$ & Pelatihan kerjasama tim \\
\hline & $\begin{array}{l}\text { Mengevaluasi hasil pelaksanaan kegiatan penyajian makanan sesuai } \\
\text { kebijakan dan standar perusahaan. }\end{array}$ & $\begin{array}{l}\text { Pelatihan manajemen penyajian } \\
\text { makanan }\end{array}$ \\
\hline
\end{tabular}

Sumber : Pengolahan dan analisis data, 2013

\section{Strategi Peningkatan kompetensi SDM melalui Program Sertifikasi dan Standarisasi.}

Salah satu upaya dalam meningkatkan kompetensi SDM adalah dengan menetapkan standar kompetensi, melaksanakan uji kompetensi dan sertifikasi profesi berbasis kompetensi. Pengembangan sertifikasi kompetensi kerja yang dilakukan oleh BNSP dengan 
mengembangkan SKKNI bersinergi dengan pengembangan pelatihan berbasis kompetensi di lembaga-lembaga pelatihan kerja sebagai kesatuan Sistem Latihan Kerja Nasional (SISLATKERNAS) (Bappenas 2008).

Beberapa strategi yang diajukan adalah:

1. Program Standardisasi

a. Pengembangan pedoman pemanfaatan dan pelaksanaan SKKNI (Standard Kompetensi Kerja Nasional Indonesia) di industri serta menetapkan kebijakan bagi industri agar menerapkannya dalam program pengembangan SDM di masing-masing entitas usaha.

b. Penetapan standard minimal sebagai syarat ketersediaan sarana prasarana pendidikan/pengajaran bagi lembaga pendidikan untuk dapat memenuhi kebutuhan proses belajar-mengajar yang kondusif.

2. Program Sertifikasi

a. Pengembangan sistem pelaksanaan sertifikasi profesi yang lebih efektif memberikan manfaat bagi industri sehingga memotivasi baik individu, manajemen dan pemilik usaha untuk menerapkannya sebagai bagian program pengembangan SDM internal

b. Pengembangan sistem sertifikasi profesi dengan mengakomodasi standar dan perkembangan yang ada di tingkat regional maupun internasional

c. Penguatan lembaga pendidikan untuk juga berperan aktif sebagai pelaksana sertifikasi SDM, sesuai bidang keahlian lulusan.

\section{Model Peningkatan Kompetensi SDM Sektor Hotel dan Restoran}

Peningkatan kompetensi SDM sektor hotel dan restoran sangat ditentukan oleh tiga faktor, yaitu : industri, kebijakan pemerintah, dan institusi pendidikan. Masing - masing pihak memberikan kontribusi terhadap peningkatan kompetensi. Pemetaan dan analisis peran sistem 'triple helix' (industri, pemerintah dan akademisi) akan menghasilkan Model Peningkatan Kompetensi SDM Sektor Hotel dan Restoran. (Gambar 4.1)

Gambar 4.1

Model Peningkatan Kompetensi SDM Sektor Hotel dan Restoran

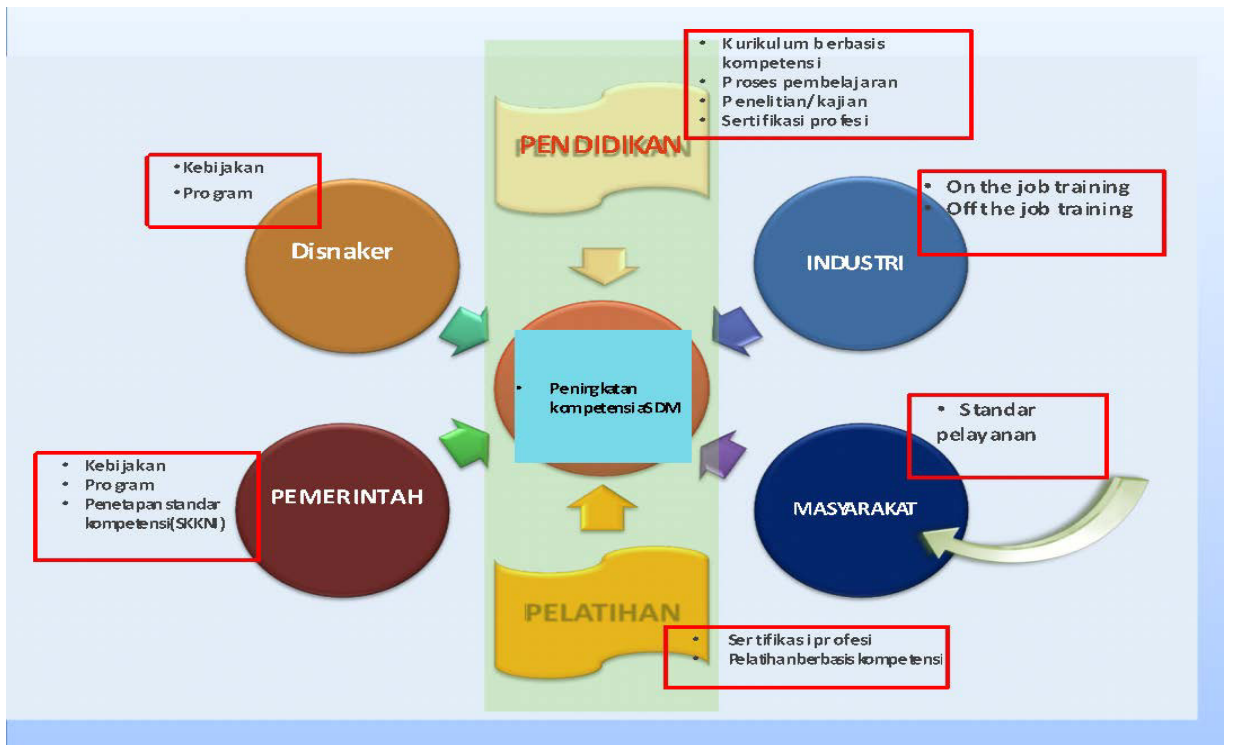


Dari Gambar 4.1 dilihat bahwa peningkatan kompetensi SDM akan melibatkan triple helix (industri, pemerintah dan akademisi).

\section{Simpulan}

Peran masing masing pihak dapat dijelaskan sebagai berikut:

1. Industri termasuk didalamnya adalah lingkungan bisnis (dalam bentuk masyarakat pengguna entitas usaha). Masyarakat memiliki standar pelayanan yang diinginkan. Sehingga upaya perusahaan untuk mengetahui standar tersebut menjadi sangat penting. Standar pelayanan yang diinginkan masyarakat dapat menjadi input untuk menentukan kompetensi yang dibutuhkan untuk memenuhi standar tersebut. Industri dalam hal ini perusahaan berkewajiban untuk memberikan pelatihan (on the job dan off the job training) untuk memastikan bahwa SDM perusahaan memiliki standar pelayanan yang diinginkan.

2. Pemerintah, termasuk didalamnya Dinas Tenaga Kerja Kota Bandung, memiliki peran yaitu : menetapkan standar kompetensi nasional (SKKNI) dan menetapkan kebijakan dan program agar SDM sektor hotel dan restoran secara bertahap memiliki kompetensi sesuai SKKNI

3. Institusi pendidikan dan pelatihan.

Institusi pendidikan memiliki peran sebagai berikut :

a. Menyusun kurikulum berbasis pada kompetensi yang dibutuhkan saat ini dan melakukan prediksi tentang kompetensi yang dibutuhkan saat yang akan datang

b. Melakukan proses pembelajaran yang berkualitas

c. Melakukan penelitian/kajian yang hasilnya dapat diterapkan pada industri hotel dan restoran

d. Melakukan sertifikasi profesi.

Institusi pelatihan memiliki peran sebagai berikut :

a) Melaksanakan pelatihan peningkatan kompetensi

a. Melakukan sertifikasi profesi. 


\section{Daftar Pustaka}

Arikunto, Suharsimi.2010. Prosedur penelitian suatu pendekatan praktik. PT. Rineka Cipta:33

BPS Kota Bandung. 2012.Bandung dalam Angka 2011

BAPPENAS. 2008. Pengembangan SDM Kepariwisataan di Indonesia.

Badan Pusat Statistik Kota Bandung.2011. Kota Bandung dalam Angka

Disbudpar Jawa Barat. 2008. Statistical Report on Visitor Arrivals to Indonesia

KEP. 239/MEN/X/2004 tentang Penetapan SKKNI Sektor Pariwisata Subsektor Hotel dan Restoran

Perda Kota Bandung No. 07 Tahun 2012 BAB X tentang Pelatihan Sumberdaya Manusia, standarisasi, Sertifikasi, dan Tenaga Kerja

Publikasi Disbudpar Propinsi Jawa Barat.2008

Rencana Pembangunan Jangka Menengah Daerah (RPJMD) Kota Bandung Tahun 2009-2013

Robbin, Stephen P.2010. Perilaku Organisasi. Jakarta: PT INDEKS Kelompok Gramedia:357

Spencer and Spencer. 1993. Competence at Work: Model for Superior Performance, John Wiley \&Sons, Inc, New York:9 dan 11

Undang-Undang No. 13 / 2003 tentang ketenagakerjaan

Yuniarsih, Tjutju dan Suwatno. 2008. Manajemen Sumberdaya Manusia, Alfabeta:22

http://diskominfo.jabarprov.go.id

bisnis-jabar.com 